ELORE (ISSN 1456-3010), vol. 17 - 1/2010.

Julkaisija: Suomen Kansantietouden Tutkijain Seura ry.

[http://www.elore.fi/arkisto/1_10/ajankoht_hammar_1_10.pdf]

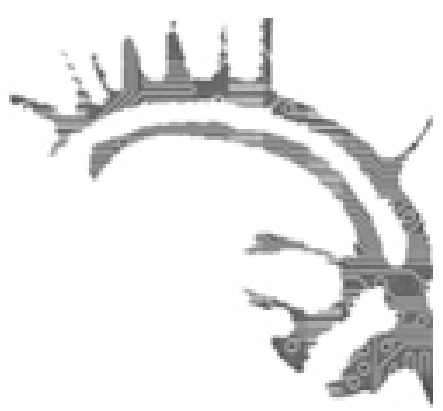

Ajankohtaista

\title{
AsiakKaAna erilaisuUs - KultTUURIEN VÄLISEN VIRANOMAISTOIMINNAN ETNOGRAFIA
}

\author{
Lectio praecursoria Joensuun yliopistossa 4.12.2009
}

\section{$\underline{\text { Sari Hammar-Suutari }}$}

Elämme haasteellista aikaa. Monenlaiset maailmanlaajuiset ilmiöt ja niiden seuraukset vaikuttavat elämäämme monin tavoin nopeammin ja konkreettisemmin kuin aikaisemmin. Ajallemme tyypillistä on, että niin ihmisten, tavaroiden, rahan kuin tiedonkin liikkuvuus lisääntyy. Elin- ja toimintaympäristömme muuttuu samalla entisestä poikkeavalla tavalla monimuotoiseksi. Kokemusmaailmaamme ulottuvat nopeat muutokset vieraiksi koettuine elementteineen aiheuttavat helposti epävarmuutta, joka voi ilmetä erilaisina vastareaktioina: esimerkiksi haluttomuutena jakaa elintilaa uusien tulijoiden kanssa. Koettu erilaisuus tuntuu vaikealta hallita, jos ja kun sitä ei voida sovittaa vanhoihin toimintamalleihin ja -käytäntöihin.

\section{JULKISELLA SEKTORILLA KESKEINEN ROOLI ELINYMPÄRISTÖN MONIMUOTOISTUESSA}

Yksi epävarmuutta aiheuttava tekijä on elinympäristön kulttuurinen monimuotoistuminen, vaikka Suomi ei olekaan koskaan ollut erityisen monokulttuurinen maa. Päinvastoin vallitseva kulttuurinen monimuotoisuus on ollut täällä moniulotteista, ja erilaisten kulttuuristen elementtien kohtaamista on tapahtunut niin kielten, elinkeinojen, uskontojen kuin arvojenkin alueilla. Suomalaiset ovat tottuneet elämään omanlaisekseen muodostuneen erilaisuuden kanssa, mutta uusien alueiden lainausmerkeissä altistuminen kulttuurisen kirjon lisääntymiselle, muun muassa nopeutuneen 
maahanmuuton seurauksena, tuo tullessaan omat haasteensa. Kohtaammekin kaupunkikuvassa, työelämässä, palveluissa, harrastuksissa, politiikassa - kaikilla elämän alueilla yhä enemmän erilaisia taustoja omaavia ihmisiä.

Meidän ei välttämättä tarvitsekaan mennä hakemaan kulttuurisesti monimuotoista asuinympäristöä Helsingin itäisistä lähiöistä, Vantaan Hakunilasta, Turun Varissuolta tai Tampereen Hervannasta. Käytännössä jokaisesta suomalaisesta kunnasta löytyy ulkomaalaistaustaista väestöä, sen lisäksi että jokaisella paikkakunnalla on luonnostaan oma moninainen asujaimistonsa. Myös esimerkkejä onnistuneista tai vähemmän onnistuneista kulttuurien välisistä kohtaamisista löytyy ihan kotipihaltamme: tänä syksynä keskustelua on Pohjois-Karjalassa käyty muun muassa Kontioniemen vastaanottokeskuksen ja kyläläisten välisistä suhteista (esim. Karjalainen 29.8.2009).

Viime aikoina pohdinta kulttuurisesta monimuotoisuudesta ja monikulttuurisen yhteiskunnan rakentumisesta on saanut laajempaakin julkista huomiota. Mediassa keskustelua ovat aiheuttaneet muun muassa turvapaikanhakijoiden ja erityisesti yksin tulleiden alaikäisten määrän lisääntyminen, niin sanottujen EU-kerjäläisten näkyminen katukuvassa ja heihin kohdistuneet toimenpiteet, työttömyyden seurauksena toimeentulotukiasiakkaiksi muuttuneet ulkomaalaistaustaiset alun perin työn perässä Suomeen muuttaneet henkilöt, ongelmat saada kuntapaikkoja pakolaisstatuksen saaneille tai löytää tarpeeksi suuria asuntoja monilapsisille maahanmuuttajaperheille.

Edellä olevasta listasta on helppo huomata, että yhteiskunnan monimuotoistuminen koskettaa oleellisesti julkista sektoria, ja esimerkiksi muutokset väestörakenteessa näkyvätkin nopeasti muutoksina viranomaisten asiakaskunnassa. Suomeen tultuaan maahanmuuttanut henkilö joutuu ensi töikseen asioimaan usean eri viranomaisen kanssa, joten julkisella sektorilla on suuri rooli myös tulijoiden integroimisessa suomalaiseen yhteiskuntaan. Asiakaspalvelussa työskentelevät virkailijat toimivat usein ensimmäisinä, ja joskus ainoina, oppaina tutustuttaessaan maahanmuuttaja-asiakkaita uuteen elinympäristöönsä sekä sen suomiin mahdollisuuksiin ja velvollisuuksiin. Asiakaskunnan kirjavoitumisen myötä virkailijat kohtaavat yhä enemmän asiakkaita, joiden tausta tai elämäntilanne on heille vieras, ja joiden palvelutarpeisiin voi olla vaikea vastata. Työskentely-ympäristönsä muuttuessa virkailijat joutuvat myös ratkaisemaan monia uusia eteen tulevia ongelmia, joihin ei ole vielä olemassa selviä toimintaohjeita. Tuoreena esimerkkinä tällaisesta tilanteesta voidaan mainita työn perässä Suomeen tulleiden ja nyt työttömiksi jääneiden virolaisten toimeentulotukiasiakkuudessa ilmenneet ongelmat: ministeriötaso ei osaa ohjeistaa asiassa sosiaalitoimistoja, joten virkailijat joutuvat itse pohtimaan tuen myöntämisperusteita ja kriteereitä niiden jatkumiselle (ks. Helsingin Sanomat 28.10.2009).

\section{KOETUN ERILAISUUDEN KOHTAAMINEN VIRANOMAISTOIMINNASSA}

Väitöskirjatutkimukseni aiheena on suomalaisten viranomaisten valmius kohdata kulttuurisesti erilaisiksi kokemiaan asiakkaita. Tutkimuksessa pohditaan myös sitä, miten yhdenvertaista palvelua voi viranomaistoiminnassa edistää. Kun puhutaan 
Sari Hammar-Suutari: Asiakkaana erilaisuus - Kulttuurien välisen viranomaistoiminnan etnografia

kulttuurisesti erilaiseksi koetusta asiakkaasta, tarkoitetaan useimmiten juuri maahanmuuttaja- tai ulkomaalaistaustaista henkilöä. Kuitenkin erilaisuutta koetaan välillä sellaistenkin asiakkaiden kanssa, joilla ei ole tällaista taustaa. Kulttuurisesti erilainen asiakas voi siten virkailijan kokemuksen mukaan hyvinkin olla myös Suomen kansalainen, joka puhuu äidinkielenään suomea tai ruotsia ja joka on viettänyt ainakin suurimman osan elämästään suomalaisen yhteiskunnan piirissä. Esimerkiksi Suomen niin sanotut vanhat vähemmistöt, varsinkin romanit, nousivat tutkimuksen aikana selvästi esille virkailijoiden pohtiessa kulttuurisesti erilaisiksi koettuja asiakkaita. Myös Suomeen adoptoidut henkilöt kokevat usein heitä kohdeltavan viranomaispalveluissa erilaisina. Monesti virkailijan voi kuitenkin olla vaikeaa tarkasti eritellä, miksi asiakaspalvelutilanteeseen liittyy erilaisuuden elementtejä.

Väitöskirjassani tarkastelen suomalaisten viranomaisten kulttuurien välisten valmiuksien ohella virkailijoiden sopeutumisprosessia työn muuttuessa ja asiakaskunnan monimuotoistuessa. Keskeisenä tutkimuskysymyksenä on: miten kulttuurinen monimuotoisuus vaikuttaa viranomaistyöhön Suomessa? Vastauksia tähän kysymykseen olen hakenut keräämällä tietoa virkailijoiden ja asiakkaiden tasa-arvo- ja yhdenvertaisuuskäsityksistä, heidän kulttuurien välisen työn valmiuksistaan sekä asiakaspalvelussa tarvittaviin toimintavalmiuksiin liittyvistä yhdenvertaisuuden edistämisen kehittämistarpeista. Lisäksi arvioin tutkimuksessa toimintatutkimuksellisen työyhteisön kehittämistoiminnan soveltuvuutta käytettäväksi julkisten sosiaalipalvelujen työyhteisöissä.

Tutkimusongelmaa lähestyin erilaisuuden, kulttuurin ja monikulttuurisuuden käsitteiden kautta. Samalla pohdin erilaisilla kulttuurien välisen työn areenoilla tasa-arvon ja yhdenvertaisuuden, kulttuurien välisyyden sekä kulttuurien välisen kompetenssin merkityksiä. Tärkeää oli myös viranomaistoiminnan reunaehtojen tarkastelu, onhan virkailijoiden työ julkisella sektorilla tiukasti sidottu ylhäältä päin annettuihin lakeihin ja säädöksiin. Valtakunnan tason ohella oli muistettava myös Euroopan Unionin vaikutukset jäsenmaidensa poliittisiin päätöksiin, jotka näkyvät viime kädessä myös viranomaisten ohjeistuksissa. Koska tutkimuksen tavoitteena oli päästä tarkastelemaan niin viranomaistyöhön liittyviä kulttuurisen muutoksen ilmentymiä kuin niihin vaikuttaneita rakenteellisia tekijöitä, sisältää tutkimuksen teoreettinen viitekehys piirteitä sekä sosiaalisen konstruktionismin että kriittisen realismin lähestymistavoista.

Pääasiassa Itä-Suomen alueella suoritetun tutkimuksen aikana haastattelin sekä viranomaisia että ulkomaalaistaustaisia henkilöitä ja romanikulttuurin edustajia. Tutkimusaineiston hankintaan kuului myös kolmen työyhteisön eli yhden Kansaneläkelaitoksen toimiston, yhden sosiaalitoimiston sekä yhden työvoimatoimiston kanssa toteutettu kehittämiskokeilu. Työskentely kyseisten työyhteisöjen kanssa perustui demokraattisten keskustelujen ympärille muodostuneisiin istuntoihin, joiden aikana pohdittiin käsiteltävään aihepiiriin, kulttuurien välisen työn valmiuksiin ja yhdenvertaisuuteen, liittyviä kysymyksiä. Menetelmällisesti tutkimus perustuu etnografisia menetelmiä ja toimintatutkimusta yhdistävän etnografisen toimintatutkimuksen sovellutukseen, jota työssäni nimitän toiminnan etnografiaksi. Tämän menetelmäyhdistelmän avulla syntyneen monimuotoisen aineiston kautta pyrin tutkimuksessa paitsi luomaan kuvausta ja analyysia virkailijoiden kulttuurien välisen työn valmiuksista myös esittelemään yhdenvertaisemman asiakaspalvelun edistämiseen tähtäävän käytännönläheisen kehittämistoiminnan mallin virkailijoiden ja viranomaistyöyhteisöjen käyttöön.

Elore $1 / 2010$ 


\section{SAMANLAISEN KOHTELUN PERIAATE JA KAPEA KULTTUURIKÄSITYS ESTÄVÄT YHDENVERTAISUUDEN TOTEUTUMISTA ASIAKASPALVELUSSA}

Tutkimuksessa kävi ilmi, että kulttuurien väliset asiakaspalvelutilanteet koetaan usein turhauttavina sekä virkailijoiden että asiakkaiden näkökulmasta. Syynä on usein palvelun tarpeiden ja tarjonnan kohtaamattomuus, mutta myös kielivaikeudet tai kulttuurisiksi tunnistettujen piirteiden vuorovaikutukseen tuoma outous voivat vaikeuttaa kanssakäymistä. Tutkimusaineistossani virkailijat nostivat esille erilaisuutta asiakaspalvelutilanteeseen tuovista seikoista muun muassa ulkonäköön, ymmärtämiseen, käytökseen ja asiointivalmiuksiin liittyviä seikkoja.

Yksi merkittävä tekijä, joka myös tämän tutkimuksen mukaan vaikuttaa kulttuurien välisiin toimintavalmiuksiin, on se, että suomalaisessa viranomaistoiminnassa suhtautumista erilaisuuteen värittää voimakas tasa-arvoisuuden vaatimus, jolla käytännössä tarkoitetaan samanlaisen palvelun tarjoamista kaikille asiakkaille. Toimintakentän monimuotoistuessa tämän muodollisena näyttäytyvän tasa-arvovaatimuksen mukaisesti toimittaessa törmätään kuitenkin yhä useammin erilaisiin ongelmiin, kun asiakkaiden taustat, elämäntilanteet ja siten myös palvelutarpeet poikkeavat laajemmalla kirjolla toisistaan. Toimintavalmiuksien taustalla vaikuttaa myös se, miten kulttuuri ja monikulttuurisuus käsitetään.

Tutkimusaineistosta noussut kulttuurikäsitys näyttäytyi suhteellisen kapeana tulkintana kulttuureista erillisinä yksikköinä, jolloin kulttuurien kohtaamista ja eri kulttuurista taustaa edustavien vuorovaikutusta lähestytään lähinnä erojen kautta. Myös monikulttuurisuuden käsittäminen lähinnä ulkoapäin tulleiden vaikutuksen rantautumisena kaventaa muun muassa niitä mahdollisuuksia, joita paikallistasolla voisi olla tarjottavana palvelujen järjestämisen suhteen. Tiivistetysti voisikin sanoa, että yhdenvertainen asiakaspalvelu ei voi riittävästi toteutua, jos yhteiskunnan eri tasoilla ei pystytä avaamaan sekä tasa-arvoon että kulttuuriin ja monikulttuurisuuteen liittyviä käsityksiä enemmän yhdenvertaisuuden ja joustavamman, erilaiset monimuotoisuutta tuottavat perusteet huomioon ottavan, monikulttuurisen yhteiskunnan suuntaan. Yhdenvertaisempi asiakaspalvelu vaatii silloin myös enemmän asiakkaiden henkilökohtaisten tilanteiden ja tarpeiden huomioimista.

\section{ASIAKKAIDEN MONIMUOTOISTUVAT TARPEET HAASTAVAT VIRKAILIJOITA KULTTUURIEN VÄLISEN TYÖN VALMIUKSIEN KEHITTÄMISEEN}

Tutkimuksesta käy ilmi, että suomalaiset viranomaiset tiedostavat melko hyvin tarvitsevansa parempia kulttuurien välisen työn valmiuksia ja he haluavat myös pyrkiä palvelemaan asiakkaitaan mahdollisimman oikeudenmukaisesti. Pyrkimykset työn kehittämiseen ovat jääneet kuitenkin vielä toistaiseksi pinnallisiksi. Tutkimuksen aikana toteutetut työyhteisöjen kehittämiskokeilut kuitenkin osoittivat, että pitkäjänteisemmän 
osallistavan työskentelyn avulla voidaan saavuttaa kehittymistä kaikilla kulttuurien välisen kompetenssin ulottuvuuksien eli asenteiden, tietämyksen, taitojen sekä toiminnan alueilla. Tämä onkin tärkeää, sillä viranomaistyössä tarvittavien valmiuksien vahvistuminen edellyttää kokonaisvaltaista lähestymistapaa, jotta kompetenssin eri ulottuvuudet voivat tukea toinen toisiaan. Jos virkailija ei pysty toiminnallaan osoittamaan valmiuttaan erilaisuuden kohtaamiseen asiakaspalvelutilanteessa, voi asiakkaan saama kohtelu olla eriarvoistavaa, vaikka virkailijan asenteet olisivat kohdallaan ja hänellä olisi paljon tietämystä sekä periaatteessa myös taidollista osaamista.

Kulttuurien välinen kompetenssi on osa viranomaisilta vaadittavaa ammattitaitoa. Vahva ammattitaito puolestaan auttaa virkailijaa kohtaamaan työssään yllättäviäkin eteen tulevia asioita. Ammatillinen varmuus antaa myös joustonvaraa tulkinnoissa silloin, kun joudutaan käyttämään esimerkiksi selvien ohjeiden puuttuessa enemmän omaa harkintaa. Erilaisuuden kohtaamisessa epävarmuudella ja sen tuomalla pelolla on vaikutusta sekä asiakkaan että virkailijan käyttäytymiseen asiakaskohtaamisessa. Luottamus omaan osaamiseen ja erilaisten tilanteiden hallintaan antaa virkailijalle varmuutta toimia tarkoituksenmukaisesti vuorovaikutustilanteissa, jolloin asiakkaalla on paremmat mahdollisuudet saada laadukasta ja mahdollisimman yhdenvertaista palvelua.

Yhdenvertaisempaan asiakaspalveluun pyrkiminen niin yksilöllisellä kuin työyhteisö- tai organisatorisella tasolla edellyttää kuitenkin erityisen oppimisprosessin, niin sanotun muutosoppimisen, läpikäymistä. Lisäksi tarvitaan valmiutta muutokseen, tarpeeksi vahvaa tahtotilaa ja sitoutumisen astetta sekä kykyä sijoittaa uudet merkitykset tarkoituksenmukaisella tavalla uudenlaiseksi muuttuneeseen ja alati muuttuvaan käytäntöön. Tämä tutkimus vahvisti käsitystä siitä, että virkailijoiden työskentelyolosuhteisiin voidaan oleellisesti vaikuttaa myös turvaamalla riittävä tiedonkulku - niin viranomaisorganisaatioiden sisällä kuin niiden ulkopuolellakin - jotta virkailijoiden työssään kohtaamien tilanteiden luonne voidaan huomioida erilaisia heidän työtään ohjaavia toimintaohjeita, lakeja ja säädöksiä laadittaessa. Näin virkailijoiden ammattitaito, mukaan lukien heidän kulttuurien välisessä työssä tarvittavat valmiutensa, voitaisiin valjastaa tehokkaasti käyttöön erilaisista taustoista ja lähtökohdista asiakkaiksi saapuvien henkilöiden kanssa työskenneltäessä. Ehkäpä esimerkiksi kulttuurisesta monimuotoisuudesta voisikin näin ollen tulla jonakin päivänä niin tavanomaista, että erilaisuutta ei enää tarvitsisi kokea epävarmuutta ja pelkoa aiheuttavana tekijänä viranomaistoiminnassa - tai muuallakaan suomalaisessa yhteiskunnassa.

Mutta vielä on kuljettava jonkin matkaa, jotta voisimme saavuttaa tämän ideaalin tilan. Päätänkin tämän lektiopuheeni samaan sitaattiin työhallinnon virkailijan haastattelusta, jolla aloitan väitöskirjani:

\section{Kyllä varmasti on tällaisia koulutuksellisia tarpeita meidän henkilökunnalla, että osattaisi kobdata kaikkia erilaisia.}

Filosofian tohtori Sari Hammar-Suutari työskentelee tutkijana Itä-Suomen yliopiston humanistisella osastolla. Parhaillaan hän on mukana Suomen Akatemian tutkimushankkeessa Kulttuurien välinen vuorovaikutus kohtaamisen areenoilla (< www.uta.fi/projektit/saiia >).

Elore $1 / 2010$ 